Diabetologia 5, 304-308 (1969)

\title{
Insulin in Bile
}

\section{The Effect of Monosaccharides and Hypoglycaemic Agents}

\author{
A.R. Boyns, N. Pearce, and R.F. Mahler \\ Tenovus Institute for Cancer Research and Department of Metabolic Medicine, Welsh National School of Medicine, \\ Cardiff, Wales
}

Received: November 4, 1968

\begin{abstract}
Summary. Immuno-reactive insulin is found in the hepatic bile of normal rabbits. Less than $1 \%$ of an injected dose of bovine insulin reached the bile. When ${ }^{125} \mathrm{I}$-bovine insulin alone or complexed with antibody was given intravenously, only $40 \%$ of the radioactivity recovered in the bile was precipitable with trichloracetic acid, and less than $10 \%$ reacted with guinea pig anti-insulin serum. Glucose, fructose, galactose, tolbutamide and phenformin all caused an elevation in bile insulin, which reached a maximum 40 to $50 \mathrm{~min}$ after the injection. Alloxan attenuated or abolished these responses.
\end{abstract}

L'insuline dans la bile. L'effet de monosacharrides et d'agents hypoglycémiants

Résumé. On trouve de l'insuline immunoréactive dans la bile hépatique de lapins normaux. Moins de 1\% d'une dose injectée d'insuline bovine atteint la bile. Quand de l'insuline bovine ${ }^{125} \mathrm{I}$, seule ou liée à l'anticorps, est administrée par voie intraveineuse, seulement $40 \%$ de la radioactivité retrouvée dans la bile est précipitable avec l'acide trichloracétique et moins de $10 \%$ réagit avec le sérum anti-insuline de cobaye. Le glucose, le fructose le galactose, le tolbutamide et la phenformine provoquent tous une élévation de l'insuline dans la bile, qui atteint son maximum 40 à $50 \mathrm{~min}$ après I'injection. L'alloxane atténue ou abolie ces réponses.

Insulin im Gallensaft. Wirkung von Monosacchariden und blutzuckersenkenden Substanzen

Zusammenfassung. Immunoreaktives Insulin wird in der Leber-Galle normaler Kaninchen gefunden. Weniger als $1 \%$ einer injizierten Dosis von Rinder-Insulin erreicht die Galle. Wenn man reines oder an Antikörper gebundenes ${ }^{125} \mathrm{I}$-Rinderinsulin intravenös verabreicht, lassen sich mit Hilfe von Trichloressigsäure nur $\mathbf{4 0 \%}$ der Radioaktivität ausfällen, die in der Galle gefunden wird, und weniger als $10 \%$ reagieren mit Meerschweinchen-AntiInsulinserum. Glucose, Fructose, Galaktose, Tolbutamide und Phenformin verursachen ein Ansteigen von Insulin in der Galle, welches ein Maximum innerhalb von 40 bis $50 \mathrm{Min}$. nach der Injektion erreicht. Alloxan vermindert oder hebt diese Effekte auf.

Key-words: Insulin, bile, rabbit, ${ }^{125}$ I-insulin, glucose, galactose, fructose, tolbutamide, phenformin, liver.

\section{Introduction}

Immuno-reactive insulin has been found in the hepatic bile of a number of animals including man (Lopez-QuiJada and Goni, 1967; DaNiel and HexDERSON, 1967). It increases in amount after an intravenous injection of glucose in a similar manner to plasma insulin, and an infusion of insulin into the portal vein produces an increased concentration of insulin in the bile (LoPEZ-QUIJADA and GoNI, 1967). Recently JEFECOATE (1968) has shown that gall bladder bile contains substances which interfere with the estimation of immuno-reactive insulin. In this study we have investigated the validity of the assay applied to freely flowing bile-duct bile, and have studied the effect on biliary insulin flow of a variety of stimuli which are known to cause a release of insulin.

\section{Methods}

1. Immuno-reactive insulin (IRI) in hepatic bile was measured by a double antibody method based on that of Morgan and Lazarow (1963). Human insulin (NOVO) was used as standard, and insulin concentrations were expressed as micro-units of human insulin $/ \mathrm{ml}$. $100 \mu 1$ of sample or standard (6.25-200 micro units $/ \mathrm{ml})$ was incubated with $200 \mu \mathrm{l}$ of guinea pig anti-insulin serum, and $100 \mu \mathrm{l}$ of ${ }^{125} \mathrm{I}$-bovine insulin for $2-3$ days at $4^{\circ} \mathrm{C}$. Then $100 \mu \mathrm{l}$ of $1 / 1000$ guinea pig serum and $50 \mu \mathrm{l}$ of rabbit anti-guinea pig serum were added. After $2 \mathrm{~h}$ at $4^{\circ} \mathrm{C}$ the precipitate was centrifuged and counted. Bile samples were stored at $-20^{\circ} \mathrm{C}$ until insulin estimation was carried out.

2. Bromsulphthalein (BSP) was obtained as a $5 \%$ aqueous solution. Its concentration in a sample of bile was expressed in terms of absorbance at $580 \mathrm{~m} \mu$, after treatment with $0.1 \mathrm{~N} \mathrm{NaOH}$ (KREBS and BRAUER, 1958). A portion of the same sample of bile treated with $0.1 \mathrm{~N}$ HCl was used as a blank. It was found that samples of bile treated with an equal volume of B.S.P. solution gave higher values for insulin than that obtained with the original sample; therefore the IRI content of bile was not measured in experiments where B.S.P. had been used.

3. Monosaccharides were of ANALAR grade.

4. ${ }^{25}$ I-Insulin (ca. $\left.50 \mu \mathrm{Ci} / \mu \mathrm{g}\right)$ was obtained from the Radiochemical Centre, Amersham. For injection this was diluted with unlabelled beef insulin.

5. Bile duct catheterization was performed through a mid-line incision in rabbits weighing between 2 and $3 \mathrm{~kg}$ under nembutal-ether anaesthesia. After ligating the cystic duct the common bile duct was ligated close to the choledoco-duodenal junction. A polyethylene 
catheter $0.5 \mathrm{~mm}$ i.d. was then inserted into the bile duct proximal to the ligature and tied in place. The catheter was brought to the surface through a separate incision and the abdomen closed. The animal was allowed to recover from anaesthesia before an experiment was carried out.

Bile was collected into plastic containers in ice over 10 min periods. The volume was measured, and after estimation of IRI concentration the total biliary insulin flow was calculated for each period. No correction was made for catheter dead space, which was small in comparison with the flow rates encountered (often $0.1-$ $0.2 \mathrm{ml} / \mathrm{min}$ ).

The amount of an injected dose of insulin reaching the bile was estimated by subtracting the pre-injection insulin flow rate from the total amount of insulin collected over the period of the experiment.

6 . Following the injection of radioactive material the total radioactivity in each $10 \mathrm{~min}$ sample of bile was measured in a crystal scintillation counter. Trichloracetic acid (T.C.A.)-insoluble radioactivity was then measured by treating a portion of each sample with an equal volume of $15 \%$ T.C.A. and counting the precipitate. Immuno-reactive radioactivity was measured by treatment of a portion of each sample with excess guinea pig anti-insulin serum $(1 / 1000)$, normal guinea pig serum (1/1000) and rabbit anti-guinea pig serum. The solution was left for $24 \mathrm{~h}$ at $4^{\circ} \mathrm{C}$, centrifuged and the precipitate counted.

7. ${ }^{125} \mathrm{I}$-bovine insulin-antibody complexes were prepared by mixing $1 \mathrm{ml}(20 \mathrm{ng})$ of ${ }^{125} \mathrm{I}$-Insulin with $1 \mathrm{ml}$ of guinea-pig anti-insulin serum, and leaving for $48 \mathrm{~h}$ at $4^{\circ} \mathrm{C}$. By precipitation with rabbit anti-guinea pig serum, over $80 \%$ of the radioactivity was antibody. bound.

8. Alloxan-treated animals were given subcutaneous$1 \mathrm{y}, 1 \mathrm{~g}$, of alloxan dissolved in phosphate buffer $\mathrm{pH} 7.5$ and left for 1 to 2 weeks before catheterization.

\section{Results} tion.

1. The effect of dilution on bile insulin concentra-

From Fig. 1 it can be seen that there was a direct proportionality between the dilution of a sample of hepatic bile and the calculated concentration of I.R.I.

2 . The recovery of added insulin from bile in vitro.

The addition of $0.25,12.5$ and $25 \mu \mathrm{U}$ of human insulin to a sample of hepatic bile resulted in almost complete recovery (Fig. 2).

3. The recovery of injected insulin in bile in vivo.

a) Unlabelled insulin

A normal catheterized rabbit was given an intravenous injection of 0.2 units of beef insulin intravenously. A gradual increase in bile insulin content followed, which reached a peak within $30 \mathrm{~min}$ (Fig. 3). However, the total collected was less than $0.1 \%$ of the injected dose. Further injections of 1.0 and 2.0 units of insulin gave similar results. b) Radioactive insulin

A catheterized rabbit was given 1.8 units of ${ }^{125} \mathrm{I}$ bovine insulin intravenously, followed by $0.2 \mathrm{ml}$. of B.S.P. solution to act as a marker in the bile. There

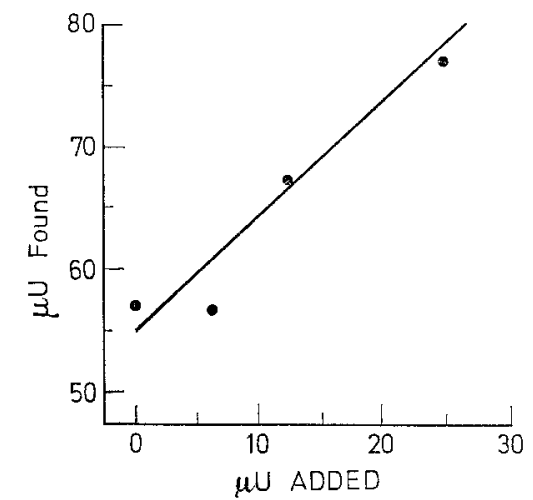

Fig. 1. A comparison of the curves given with human insulin standards and dilutions of a sample of hepatic bile in the double antibody radioimmunoassay

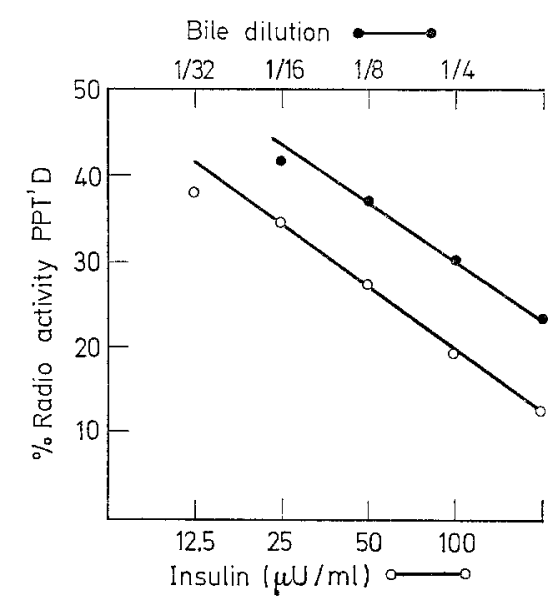

Fig. 2. The recovery of human insulin added to a sample of hepatic bile containing $55 \mu \mathrm{U}$ insulin per ml. The line represents a theoretical $100 \%$ recovery

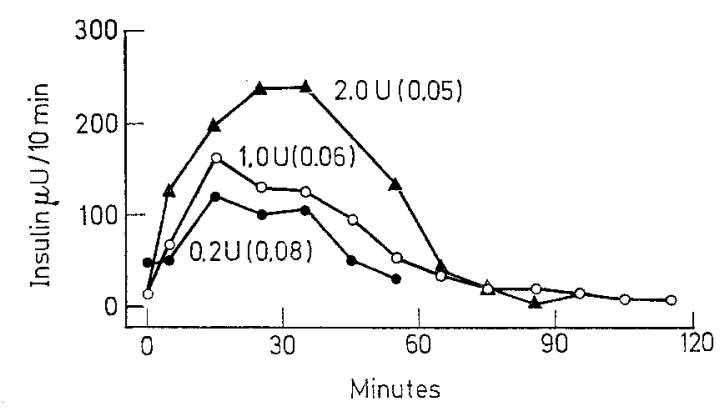

Fig. 3. The recovery of $0.2,1.0$ and 2.0 units of intravenously injected bovine insulin in bile of a normal rabbit.

The figures in parenthesis are percentage recoveries

was a rapid increase in the concentration of B.S.P. in the bile, which reached a peak after $30 \mathrm{~min}$ (Fig. 4). There was a peak of radioactivity soon afterwards, but T.C.A.-insoluble radioactivity represented less than $40 \%$ of this and showed a gradual decline over the 
period of the experiment. Less than $3 \%$ of the injected radioactivity was recovered in the bile in this time. Because of the effect of B.S.P. on the estimation of insulin (see methods), the experiment was repeated with the omission of B.S.P. Once again, less than $40 \%$ of the radio-activity was T.C.A.-insoluble, and only about $10 \%$ reacted with insulin antibody.

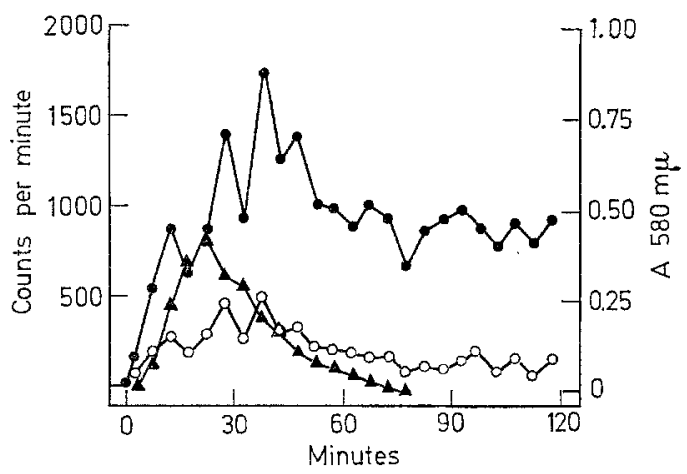

Fig. 4. The recovery of radioactivity in bile after the intravenous injection of 1.8 units of ${ }^{125} \mathrm{I}$-bovine insulin and $0.2 \mathrm{ml}$. of $\mathrm{BSP}$ solution $(50 \mathrm{mg} / \mathrm{ml})$

- Total radioactivity in each 10 min sample (counts/ $\min$ )

O-- O T.C.A.-insoluble radioactivity in each $10 \mathrm{~min}$ samplo (counts/min)

$\Delta$ - $\Delta$ B.S.P. concentration (A $580 \mathrm{mU}$ )

c) Insulin antibody complexes.

Insulin complexed with antibody is effectively a larger molecule than insulin alone. The effect of antibody on the handling of insulin was investigated. $0.65 \mathrm{ml}$ of a solution containing ${ }^{125} \mathrm{I}$-insulin-antibody complexes was given intravenously to a normal catheterized rabbit. As in the previous experiment, only about $40 \%$ of the radioactivity reaching the bile was precipitable with T.C.A., and immunoreactive material represented less than $10 \%$ of the total.

4. The effect of monosaccharides on insulin levels in the bile of normal and alloxan-treated rabbits.

Normal rabbits were given $3 \mathrm{~g}$ of glucose as a $50 \%$ solution intravenously. This caused a marked increase in the amount of insulin reaching the bile (Fig. 5). This attained a maximum after about $50 \mathrm{~min}$ and then slowly declined. Fructose and galactose caused similar but much smaller changes. Alloxan-treated animals had lower fasting levels for bile insulin and although the administration of fructose, galactose and glucose was sometimes followed by increases in biliary insulin, these were usually less than those seen in normal animals (Fig. 5).

5. The effect of tolbutamide on insulin in the bile of normal and alloxan-treated rabbits.

Using a catheterized animal, $50 \mathrm{mg}$ of tolbutamide given intravenously caused a small rise in bile insulin (Fig. 6. Rabbit A). Three hours after this injection a second injection of $100 \mathrm{mg}$ tolbutamide gave a larger rise, which reached a maximum after $60 \mathrm{~min}$. Three hours after this injection a third dose of $200 \mathrm{mg}$ had very little effect. This procedure was repeated in another rabbit, but this time starting with the highest dose (Fig. 6. Rabbit B). $400 \mathrm{mg}$ of tolbutamide caused a transient drop in bile insulin, but this was followed by a rise with a maximum after $40 \mathrm{~min}$ and a slow decline. A second injection (200 $\mathrm{mg}$ ) gave a similar response without the initial drop. A third injection
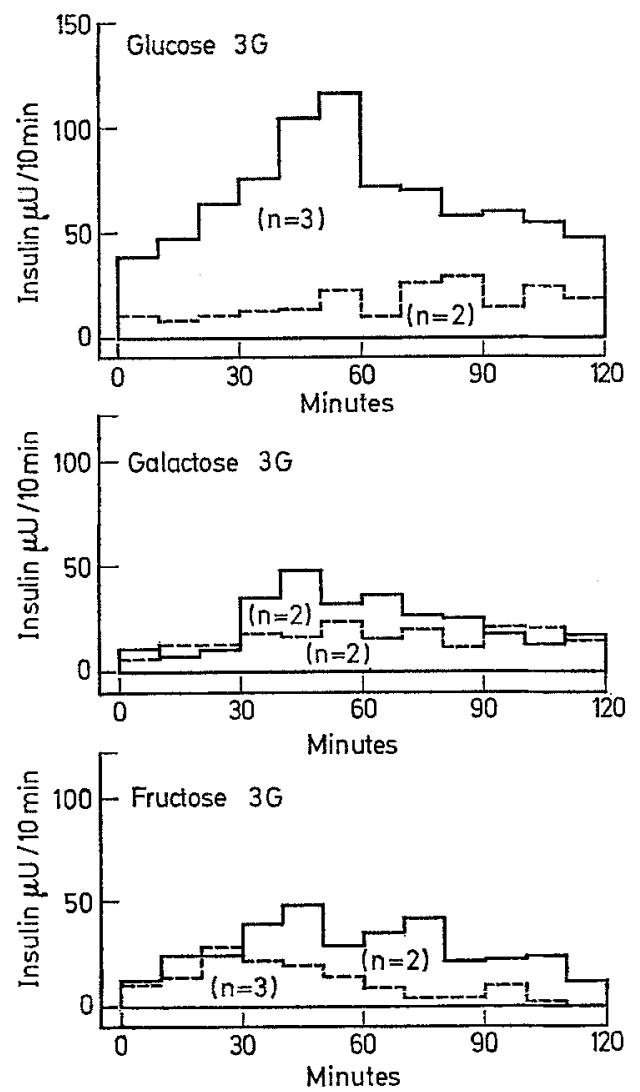

Fig. 5. The effect of intravenous injections of monosacharides on bile insulin content

- - - normal rabbits

- - alloxan-treated rabbits

(100 mg) of tolbutamide was associated with a gradual fall in the biliary insulin flow.

In contrast, 3 animals which had been treated with alloxan 2 weeks before the experiment showed little or no response to $200 \mathrm{mg}$ of tolbutamide.

6. The effect of phenformin

A normal rabbit was first given $2 \mathrm{ml}$ of saline intravenously as a control. This was associated with a fall in the total amount of bile insulin collected, mainly as a result of decreased concentration rather than decreased flow, Three hours later an intravenous injection of $10 \mathrm{mg}$ of phenformin hydrochloride in $2 \mathrm{ml}$ of saline produced a marked rise in bile insulin, which continued for $2 \mathrm{~h}$. Three hours later, i.e. one hour after the end of the previous experiment, a further injection of $10 \mathrm{mg}$ of phenformin gave a similar result (Fig. 7). By contrast, in 2 alloxan-treated animals phenformin had no effect on bile insulin flow. 
It was unfortunate that it was not possible to measure plasma insulin levels simultaneously with bile, as peripheral venous constriction after bile duct catheterization made it very difficult to obtain adequate amounts of blood. However, in uncatheterized

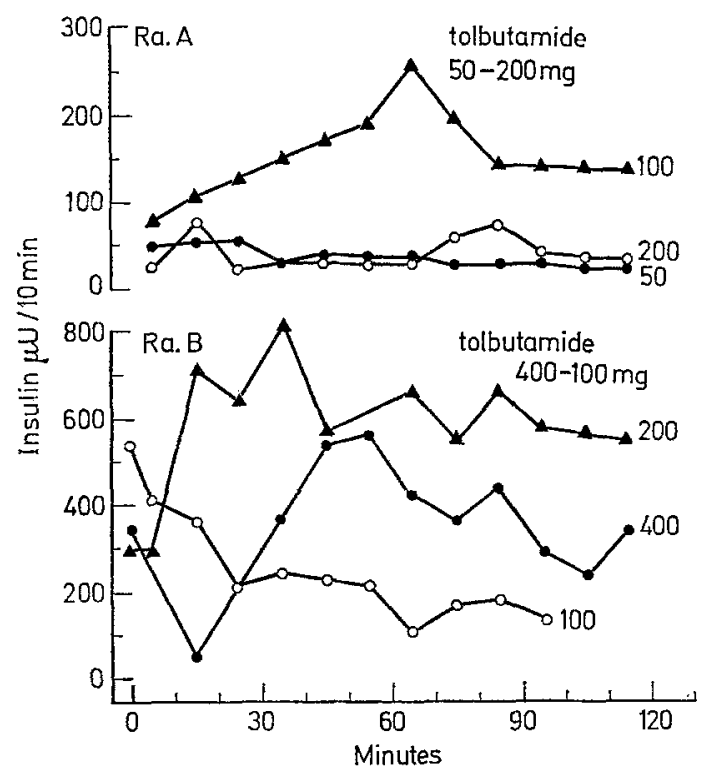

Fig. 6. The effect of repeated injections of tolbutamide on the bile insulin content of normal rabbits

Rabbit A: 50 then 100 then $200 \mathrm{mg}$ of tolbutamide Rabbit B: 400 then 200 then $100 \mathrm{mg}$ of tolbutamide

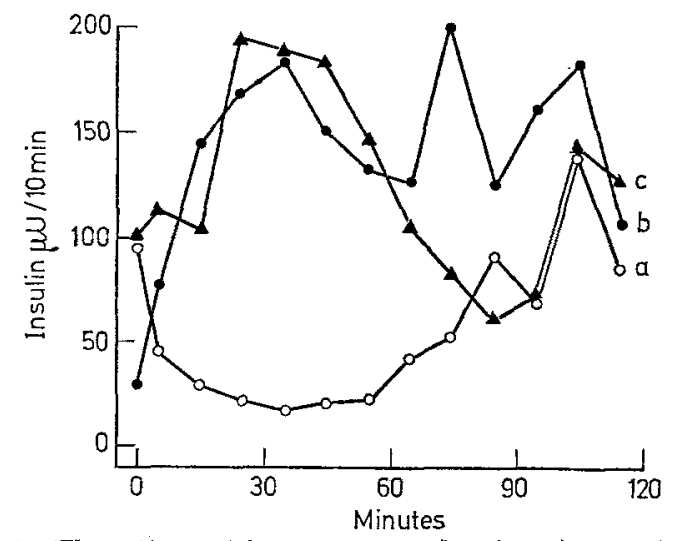

Fig. 7. The effect of intravenous phenformin on the bile insulin content of a normal rabbit

a) (O) $2 \mathrm{ml}$ of $0.15 \mathrm{M}$ sodium chloride

b) (C) and c) (A) $2 \mathrm{ml}$ of $0.15 \mathrm{M}$ sodium chloride containing $10 \mathrm{mg}$ of phenformin

animals there was a consistent rise of $10-20 \mu \mathrm{U} / \mathrm{ml}$ in plasma insulin after the administration of $10 \mathrm{mg}$ of phenformin intravenously.

\section{Discussion}

The results presented here confirm the findings of LOPIZ-QUIJADA and GONI (1967), and show that IRI, can be detected in the hepatic bile of rabbits even though the highly concentrated bile from the gall bladder may interfere with the assay (JEFFCOATE, 1968).

The dilution and recovery experiments (Figs. 1 and 2) show that the double antibody assay can be applied to freely flowing bile obtained from the bile duct by catheterization.

Only $0.1 \%$ of injected insulin appeared in the bile, and it was not possible to cause a significant increase in this fraction with increasing dosage (Fig. 3).

With radioactive insulin, $3 \%$ of injected radioactivity reached the bile but of this only one tenth reacted with specific antiserum. There was a discrepancy between the value of T.C.A.-precipitable and the immunoreactive fraction. This may have been due to an inhibitory effect of bile on the insulin-antibody reaction, but this is unlikely as the nearly complete recoveries of added insulin demonstrated (Fig. 2). Alternatively, a proportion of the T.C.A.-insoluble material may have been insulin fragments unable to react with antiserum. Insulin complexed with antibody behaved in a similar manner to insulin alone as far as appearance in bile was concerned. The experiments do not preclude the possibility that dissociation of the complexes took place in vivo, or that the small amount of insulin reaching the bile had not originally been combined with antibody.

Fructose and galactose do not stimulate insulin production by rabbit pancreas in vitro (Coore and RANDALL, 1964). The small rises in bile insulin seen after galactose and fructose in vivo are presumably due to their conversion to glucose.

Tolbutamide, which stimulates insulin release from the pancreas (COoRE and RANDALL, 1964), also caused an increase in bile insulin. This response appears to be not only dose dependent, but also capable of exhaustion by repeated stimulation (Fig. 6). A similar exhaustion of the plasma insulin response in man after repeated stimulation by tolbutamide has been reported by PFeIFFer et al. (1961).

Phenformin, which has a hypoglycaemic effect in man and may suppress insulin release stimulated by glucose (Boshelu etal., 1968), unexpectedly caused an increase in biliary insulin flow. It is not possible to deduce from these results whether this is due to a direct effect on the pancreas or some mechanism in the liver releasing insulin into the bile.

No conclusions can be drawn from these experiments on the mechanism by which insulin is transferred from blood to bile when the plasma insulin is raised. Bile has been shown to contain small amounts of different proteins, most of which are immunologically identical with plasma proteins, and the serum/bile concentration ratio for a protein decreases with decreasing molecular weight (HARDWICKE et al., 1964). It is not surprising therefore, that a small protein such as insulin is found in the bile. The present work indicates that the transfer of insulin from plasma to bile is almost as rapid as that of B.S.P., which is in part conjugated and then excreted into the bile after an initial hepatic 
uptake (Coomss, 1964). However, insulin may also reach the bile via the space of Disse as suggested by Lopez-QUIJAda and Goni (1964). Although Schultze and HeREMars (1966) have indicated that a lymphatic route may exist for other serum proteins, the actual demonstration of a physical connection between bile canuliculi and the space of Disse has, however, only been possible in pathological states (Novizorf and ESSNER, 1960).

Acknowledgements. We thank Mr. G.V. GRoom for excellent technical assistance, Dr. G.M. PowELI for advice on operative technique and Tenovus for financial support.

\section{References}

Boshelr, B.R., R.F. Roddar, and G.L. MoAdams: Effects of phenformin on insulin reserve and release. Ann. N.Y. Acad. Sci. 148, $756-767$ (1968).

Coomss, B.: The Liver, Volume II, Chapter 12, p. 21. Editor: Rouiller, Ch. New York and London: Academic Press, 1964.

COORE, H.G., and P.J. RANDLE: Regulation of insulin secretion studied with pieces of rabbit pancreas incubated in vitro. Biochem. J. 93, 66- 78 (1964).

DaNLEI, P.M., and J.R. Heinderson: Insulin in bile and other body fluids. Lancet 1967 I, $1256-1257$.

Hardwicke, J., J.G. Rankin, H.J. Baker, and R. PrerSTG: The loss of protein into human and canine hepatic bile. Clin. Sci. 26, 509-517 (1964).
JefFCOATe, S.L.: Insulin in bile: Studies on the effect of bile acids on the radioimmunoassay of insulin. Diabetologia 4, 281-285 (1968).

KREBS, J., and R. BRAUER: Metabolism of sulphobromophthalein sodium (BSP) in the rat. Amer. J. Physiol. 194, 37-43 (1958).

LOPEZ-QUiJADA, C, and P.M. GoNI: Liver and insulin. Presence of insulin in bile. Metabolism 16, 514-521. (1967).

Morgan, C.R., and A. Lazarow : Immunoassay of insulin: two antibody system. Plasma insulin levels of normal, subdiabetic and diabetic rats. Diabetes 12, 115-126 (1963).

Novirofr, A.B., and E. Essner: The liver cell. Amer. J. Med. 29, 102-131 (1960).

PherfTer, E.F., H. Ditsohuneit, and R. Ziegler : Über die Bestimmung von Insulin im Blute am epididymalen Fettanhang der Ratte mit Hilfe markierter Glucose. Klin. Wschr. 39, 415-425 (1961).

Schultze, H. E., and J.F. Heremans : Molecular biology of Human Proteins, Vol. 1, p. 808. Amsterdam: Elsevier Publishing Co. 1966.
A.R. Boyns
N. Pearce
R.F. MAHLER
Tenovus Institute for Cancer Research and Dept. of Metabolic Medicine Welsh National School of Medicine Cardiff, Wales 